\title{
Determining performance criteria of railway market: a case study
}

\author{
Muhammet Türker Ahi ${ }^{{ }^{*}}$ and Kürşat Yildiz ${ }^{2}$
}

\footnotetext{
* Correspondence: t.ahi@railistics.de ${ }^{1}$ Gazi University Technology Faculty Civil Engineering Department Teknikokullar - Beşevler, Çankaya, 06570 Ankara, Turkey

Full list of author information is available at the end of the article
}

\begin{abstract}
This paper classifies a case study on railway clusters allowing analysis of competitiveness performance criteria including the innovation capability of industries via different models. Data are collected from the Turkish railway industrial cluster; where 130 companies are located. Porters' industries Life Cycle Evolution, Diamond, Five Forces Models and SWOT Analysis are applied to explore which criteria influence at most on the cluster companies' competitiveness performances and innovation capability based on operational conditions. Porter's Life Cycle analysis showed that the cluster is between introduction and growth phase. This phase has typical characteristics such as high investment demand on R\&D, lack of qualified staff which could be compared to the performance criteria evaluated from the other three models. Another aim was to research the consistency and difference between the applied different dimension scaled models. Delivery time of the suppliers, qualified staff, capital range of the companies and physical enlargement area of the production plants were found to be the most important criteria in operational view of the competitiveness. Another result is that the applied tools are producing similar and consistent results independently from their dimension scales.
\end{abstract}

Keywords: Railway, Cluster, Innovation, Competition, Performance criteria, Decision tools

\section{Introduction}

Organized industries or specific clusters have an important role in economies across the world. Industrial clusters, networking and cooperation among companies and institutions facilitate organizational learning and enable even small and medium-sized enterprises to profit from economies (Cooke, 2002).

Cluster, network and agglomeration researches which depend on the studies of Adam Smith (1776) and Alfred Marshall (1890) became common concepts which started to be popular and comprehensively recognized in terms of innovation and effectiveness of the enterprise with Porters' “The competitive Advantage of Nations"(Mansury and Love, 2008). This popular study reflected on sectoral and regional studies as well as governmental policies. Clustering became a research field in various disciplines i.e. railways, aviation, tourism and high technology industries. The number of studies in railway sector are still insufficient when compared to other clusters and industries in which more research subjects are provided (Novelli et al., 2006). 
Industry or business clusters - defined by Porter (2002a, b) as "geographic concentrations of interconnected companies and institutions in a particular field" - can suffer from lock-in effects. Steady resource distribution then leaves companies and regions with inflexible product portfolios or business models in the light of discontinuous or long-term changes (Arthur, 1989). One solution to get rid of lock-in effects is through an effective regional innovation development that incorporates external and unorthodox knowledge into the region's and companies' learning processes (Asheim and Coenen, 2005; Tödtling and Trippl, 2005).

The more effective a cluster is, the bigger the contribution to a country's economy is (Arthur, 1989). Turkey's rail industry cluster located in Ankara, which is defined as a cluster under the national law, is one the fastest growing clusters compared to other industries. The increasing energy costs, growing energy restraints, traffic jams and raising road accidents have been leading the global strategy to invest more and more into railway transportation mode since the last 10 years (IEA, 2017). Clusters are initially established to develop the local industries. As a result, the market for local cluster services has increased and become global and highly competitive.

The aim of this paper isto identify the factors that affect the overall performance of a cluster. To achieve this, categorizations of firms are made and Diamond Model, Five Forces Model and SWOT Analysis are applied. Then the results are compared. All three models are decision and strategy management tools. Their consistency is important as they are mostly used methods by decision makers and appliers at choosing strategic measures according to the cluster performances. This paper is one of the first and most comprehensive railway cluster research in Turkey where different analysis such economic growth, R\&D demand, infrastructure and rolling stock needs, needed investment size and qualified stuff, expected future developments are analysed. One of the most important results in scientific terms was to finding out the criteria effecting the cluster performance. It describes the - the local industry's innovation capability and efficient production capacity, whereas the rail cluster in Turkey has a potential of 20 billion Euros until 2023. Therefore, the analysis of the most important performance criteria and consistency of the right decision tools to prevent risks and costs which play a crucial role in investments and future developments of the country's economy and infrastructure capacity in transportation.

Small and Medium Economic (SME) firms often locate in clusters in order to deal with resource constraints, innovation capability and being aware of competitiveness which factors are affecting each other and belong together (Bell, 2005). In order to accomplish the $R \& D$ support for a higher innovation capability in the perspective of SMEs for finding the prospective areas, they depends on the announcement of promising industry and technology from government and public institutions (Park et al., 2016). The geographic proximity and the relationships between competing and cooperating peers provide firms with cost advantages, access to less available resources, technological externalities, as well as more intense knowledge transfer (Popper 2008). While cluster companies' management innovation programs have been found that they did not directly increase companies' competitiveness performance, the alignment of these programs with knowledge management initiatives enhance performance (Magnier et al., 2017). In another words, networking and location effects in clusters have been found to develop the innovativeness of firms in these clusters (Tseng and Cheng, 2009). Although, researches show that clusters usually support 
SMEs in adopting and diffusing incremental innovation, they do not sustain innovation (Turoff et al., 2009). Bessant and others (2010) found out that after some time, that companies in clusters are more vulnerable to discontinuous changes. This can be followed back to the path-dependency of clusters, e.g. developments in the past lead to present resource constellations, which determine future actions (Porter, 2010a, b). The main problem of existing researches and industry or cluster competition analysis is due to their lack of strong theoretical background. Without a rigorous theoretical explanation, it is not clear why some factors are important for competition and others not (Cho and Moon, 2013).

Michael Porter's argument is that clusters have the potential to affect competition in three different ways: by increasing the productivity of the companies in the cluster, by driving innovation in the field, and by stimulating new businesses in the field. In the modern global economy, according to Porter, comparative advantage-how certain locations have special endowments (i.e., harbor, less cost labor) to manage high input costs-is less relevant. As a result, competitive advantage-how companies make productive use of inputs, requiring continual innovation-is more important. Reasons for clustering in the past have diminished in importance with globalization, new influences of clusters on competition have taken on growing importance in an increasingly complex, knowledge-based, and dynamic economy (Porter, 1998). In this way, with the aim to stay competitive and innovative, companies (or clusters) should consolidate links to external and non-local knowledge into their local network (Celiktas and Kocar, 2010). These links are strongly related to the cluster policies, which can be seen as a recent stage of innovation policy which is one of the important factor of the business competition. These policies are inspired by the literature built on the effective works of Allen (1983) on collective invention, Lundvall (1988) on user-producer interaction and collective learning, Freeman (1991) on innovation networks, and Porter (1998) on the benefits of co-location in industrial clusters (Rothgang et al., 2017a, 2017b).

Porter's five forces analysis is a model that serves to analyse the level of competition within an industry, a cluster and a business strategy development (Porter, 2008, 2011; Sztuka, 2011; Greenspan, 2015). Understanding the forces that shape industry competition is the starting point for developing strategy. The five forces reveal why industry profitability is what it is. Only then can a company incorporate industry conditions into strategy. The five forces reveal the most significant aspects of the competitive environment which provides an understanding of industry structure guiding toward to strategic action possibilities to better cope with the current competitive forces (Porter, 1999). It describes the industries or clusters to derive five forces that are crucial to determine the competitive intensity and therefore attractiveness of an industry or cluster. In this context, attractiveness refers to the overall industry profitability. An "unattractive" cluster is one in which the combination of these five forces acts to push down overall profitability. A cluster with high unattractiveness would be an approaching "pure competition" in which existing profits for all firms are driven to normal profit (Grieger et al., 2012; Reynders, 2012).

In the related literature, the Diamond Model is accepted as one of the leading studies (Caltagirone et al., 2013). In his earlier work, Porter (1990) developed a model which detects the key sources of competitiveness, called Diamond Model. The model shows that competitiveness is based on four interrelated influences (Viederyte and Didziokas, 
2014). It is claimed that geographical concentration increases local competitive power. The model connects buyer, supplier and other organizations with consistent and strong relations to describe the performance of the cluster. Competition in supply chains is based on a level of networks or clusters due to concurrences and cooperation between the companies and this encourages the formation of clusters (Karniouchina et al., 2013). The double diamond model which was developed by Rugman and D'Cruz (1993) recommends that managers set up upon both foreign and domestic diamonds in order to become competitive in global markets in terms of survival, profitability, and growth. Jin and Moon (2006) used Porter's Diamond Model and Double Diamond Model in order to study the competitiveness factors of Korea's apparel industry. They suggested new sources of competitive advantage factors. Chen and Ning (2002) suggest a revised framework based on Porter's diamond model in order to examine the development of e-commerce industry in less-developed countries. In the current study we use the Diamond Model to find the competitive advantages of shadow banking industry not a particular nation. (Riasi, 2015).

SWOT Analysis is mostly used to determine the business strategy in a company or cluster and consists of four elements; strengths, weaknesses, opportunities, and threats-and is a structured analysis tool to evaluate those four elements of a project or business structure. A SWOT Analysis can be carried out for a place, company, industry product or cluster. The method specifies the goal of the industry, cluster or project and identifies the internal and external elements that are favorable and unfavorable to achieve that goal (Terzić et al. 2011; FME, 2013).

None of the studies in the literature consider Diamond, Five Forces and SWOT analysis at the same time to compare the consistency of these models on a real observed data. Also, none of the researches focus on a railway cluster. Our study also determines the life cycle of the Turkish Railway Cluster by using Porter's industries life cycle model. The study aims to fill these gaps, to research the most important competition based performance factors by a broad case study on the Turkish railway cluster, where the performance factors were seen as directly related with the operation efficiency.

\section{Case description}

Data collection

The railway cluster in Turkey located in Ankara, but also covers some companies from Bursa and İstanbul, including 130 member companies, is examined with in terms of competitiveness and performance analysis in March 2016. As two decision and one strategy management models are used, no special computer software was used for the analysis of results.

Interview and survey methodologies are used to collect the data set of the railway cluster. This survey is prepared and the analysis are taken by a panel of experts by using Delphi Method: academicians, professional consultants, cluster executive board members. The purpose of the Delphi method is the reliable and creative exploration of ideas or the production of proper information for decision making. The Delphi Method is based on a structured process for collecting and distilling knowledge from a group of experts by means of a series of questionnaires interspersed with controlled opinion feedback (Adler and Ziglio, 1996). According to Helmer (1977) Delphi provides a beneficial communication 
tool among a group of experts and thus facilitates the formation of a group judgement. As the cluster is an economic case that is affected at all economic conditions (Solvell, 2008): (1) locally by microeconomic and regional development policies; (2) macroeconomic - by the country and global economic environment; (3) at company level by the economic relations inside the cluster structure. These conditions are tried to reflect in the survey questions, which consists of three sections. The first section contains profiles of the firms and the interviews with individuals. They are asked questions about e.g. their position, industrial category of the company, years of operation, company capital and revenue, international certificates, railway specific certificates and management systems, qualified staff, quality monitoring systems, number of employees, product status, and sale destinations. The second section concerns about the firms' adaptability in the changing markets and flexibility in production range including the level of innovation and the technologies used in production. The final section identifies the analysis of the criteria which affect the raise of competitiveness of the cluster in terms of higher requests, orders and revenue and which criteria affect in the opposite direction. Cluster companies are providing services and products most frequently for rolling stock sub sector e.g. tram, metro, locomotive and wagon production, control and command systems and spare parts. Engineering and design companies are fewer in number than the manufacturers.

In total, 130 cluster firms were visited for the survey. After removing invalid and not relevant replies, the sample was reduced to 93 (71.5\% of the whole cluster companies). As secondary data sources to triangulate and ground the responses and filter the data proofs such; yearly approved revenue, certificates and official documents approved by institutions, approvals and other related documents are also taken into consideration.

The survey indicates that business titles of the respondents ranged from senior managers for divisions such as sales management, import/export, production, research and development department to deputy manager or above.

Cluster companies are categorized as complete railway vehicle manufacturers $(4.3 \%)$, component producers mostly in steel, rubber and electronic products $(73.4 \%)$, engineering and design companies (2.0\%), service providers i.e. logistics, maintenance, education, certification companies and institutions etc. (20.3\%); proportions close to the national level. The majority of the surveyed firms had been in operation for two to ten years. More than $50 \%$ of the firms had less than 100 employees. The sale records show that $85 \%$ of the products are sold inland and 15\% abroad. The average increase of revenues of cluster companies is found as $20 \%$ when compared to the last 3 years.

\section{Discussion and evaluation}

Diamond, Five Forces and SWOT analysis are applied to investigate how consistent the results of the models are and which criteria are the most affecting ones on competitiveness in the real world. The adopted input data are the questions in questionnaires which are related with the performance criteria of each applied model. The methodology includes the collection of the data of 130 companies, filtering of the useable answers, analysis are done by a panel of five experts by using the Delphi Method and two of the academician experts were assigned to apply the models and validate results. In the last step, comparison of the outputs in terms of consistency between the models and results are provided. As explained in the previous chapter, earlier studies have identified a number of items that can affect the competitiveness of different clusters (e.g. maritime, 
automobile industry) which were insufficient in terms of interpreting the relation between cluster performance and competitiveness and did not applied on railway clusters at all. To fill this gap, a criteria analysis is performed and the results suggest that the most important competition performance criteria can be classified under delay of delivery time of suppliers, lacking of qualified staff, insufficient capital of companies and the restriction of physical enlargement area of companies' production plants, unplanned and short-term orders, adequate stability - reliability - quality of the suppliers, insufficient R\&D background of the cluster companies, being close to other suppliers and customers and distance to the rail and sea transport facilities and connections (further details at Table 1).

However, clustering analysis on the basis of M. Porter's Diamond, Five Forces model and SWOT analysis have their advantages explained above, the interconnection of factors and their effect on the clustering, the economic theories has not yet provided a model that allows both the analysis and the definition of a procedure for implementing a successful clustering research. The adoption of M. Porter's Diamond and Five Forces model generates convenient theoretical basis and has practical implication for real Railway sector's clustering abilities evaluation. It also supports to systemize core cluster characteristics, that can be detected in the Railway industry and measure the reasonable performance factors.

The first applied model is Diamond Model which suggests five dimensions; related (main) and supportive dimensions, demand conditions, work structure and competition, criteria conditions and state. Moreover, performance elements were added to the questionnaire by the researchers to measure the performance of Turkish Railway Clusters' competition power. The final filtering of the results was composed of six criteria. These are categorized under four main and two supportive criteria explained under 4.1.Diamond Analysis, which are based on the characteristics of the related country and company's frame conditions.

These conditions are; railway specific legislations (i.e. obligations, restrictions, different national applications), state supports for investments and R\&D activities for higher innovation capability, country's targets for the railway sector, flexibility in rapidly changing markets, innovation tendency of the markets and global economic and environmental strategies affecting cluster's structure and development behaviour.

\section{Diamond model}

Main criteria

The four main criteria are:

1. Input conditions: human resources, physical infrastructure, information sources, capital and other infrastructure parameters.

2. Demand conditions: inland demand, external demand, potential markets, attributes of demands, customers' tendency of demand, customers' selectiveness, developing market conditions.

3. Related and supporting industries: This criterion indicates suppliers who have a competitive advantage and other companies e.g. raw material suppliers, expertized machine suppliers, intermediate product suppliers and package material suppliers.

4. Company strategies and rivalry: Territorial conditions, other companies' structures which act in the same sector, reasons of establishment of these companies, competition structure in this territory, local/foreign capital structure, companies' 


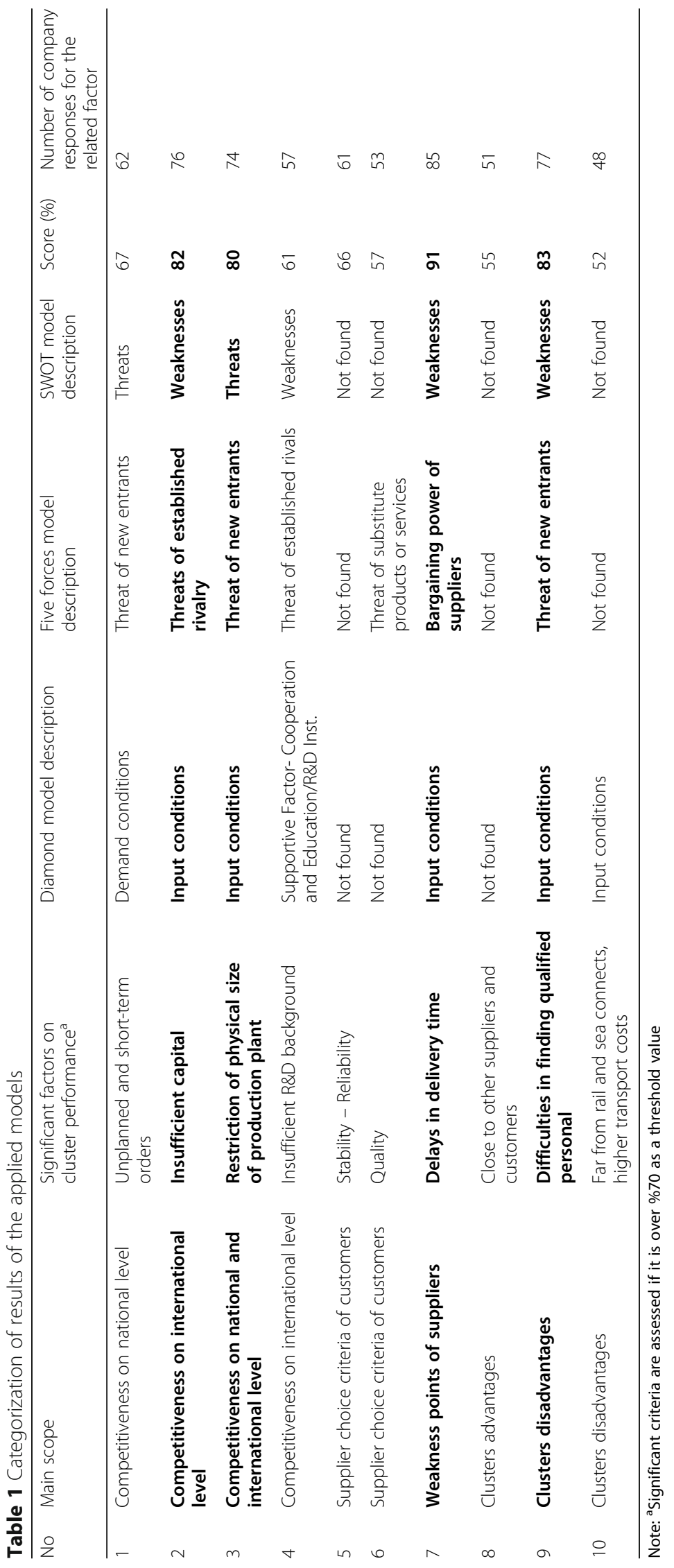


innovation capacity and approach strategies to competition, proper territory allowing for sustainable and developing competition and the national competition level.

\section{Supportive criteria}

The supportive two criteria are:

1. Government criteria: Most important actor in clustering work is the government. With a right strategy, governments are called as "a simplifying criteria for clustering". They also regulate the relationship between clusters and state institutions.

According to the literature, the government is indirectly affecting national sectors' competition power on international level. Thus the government shouldn't focus on the improvement of the competition power, it should mainly support the 4 main criteria explained under the Diamond Model below (Arsezen et al., 2013; Caltagirone et al., 2013).

2. Cooperation and education-research institutions (for innovation development): Universities, technical vocational schools, public education based private schools (courses, workshops etc.), research institutions, technology support and transfer service providers, chambers of professions and economy, labor unions, associations, development agencies are main cooperation and education-research institutions.

\section{Diamond analysis}

All criteria (dimensions) shown in the Diamond Model (see Fig. 1) are expressed with certain colours. Green means positive and red means negative effecting performance criteria in the analysis. Arrows show the relation between these criteria and cooperating institutions.

\section{Five forces analysis}

Five forces analysis determines general strategies and competition structure of the focused sectors in five dimensions. These five dimensions (Porter, 2010a, b; Rice, 2010) are:

- Bargaining power of customers (buyers)

- Bargaining power of suppliers

- Threat of new entrants

- Threat of substitute products or services

- Threat of established rivals

The "bargaining power of customers (buyers)" dimension can also be described as following market outputs; ratio of customers concentration to sellers concentration, customers trading limits, available information for customers, availability of existing substitute products and the sensitivity of customers for a product or service.

Criteria describing "the bargaining power of suppliers" dimension can be summarized as; supplier switching costs relative to company switching costs, differentiation costs degree, availability of substitute costs, supplier concentration to company concentration ratio, employee solidarity (i.e. labor unions), ratio of input costs to product or service selling costs and supply capacity of the seller. 


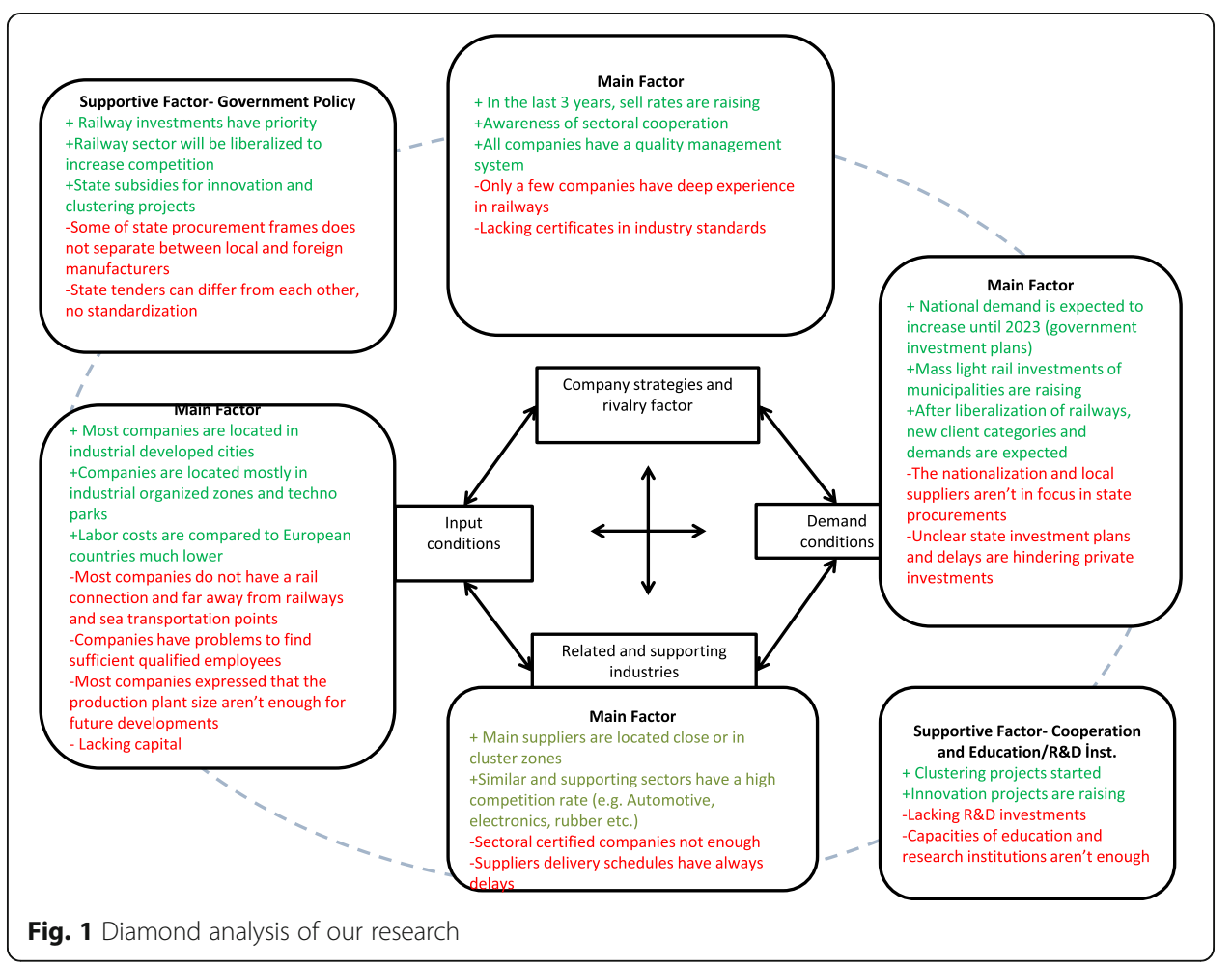

The Third dimension "threats of new entrants" have these potential criteria; the existence of entrance barriers, existing economies of scale, trust in brand, transition costs, capital needs, access to distribution channels, absolute cost advantages or disadvantages, sector profitability and government policies.

The Fourth dimension "threat of substitute products or services" can be described with these criteria; price performances of substitute products and services, transition costs of buyers, expected product differentiation costs.

The Fifth and the last dimension "threat of established rivals" is interacting between the other 4 dimensions. This dimension consists of the following criteria; high numbers in competing companies, growth rates of the related industry and excessive increase in product sizes in some intervals, high constant costs values, variety in competing actors, difficulties at accessing information, degree of advertisement and marketing expenditure.

The whole collected responses are distributed according to the descriptions of the Five Forces Model above by the panel of experts. Each expert made his own estimation about the responses and at the end a Five Forces Figure is finalized with the approval of the panel members' discussions.

Five forces analysis of Turkish Railway Cluster is given below (see Fig. 2).

\section{SWOT analysis}

SWOT analysis aims to find out the strengths, weaknesses, opportunities and threats of an industry, company or cluster and is used as a business management tool (Terzić et al., 2011; FME, 2013). 


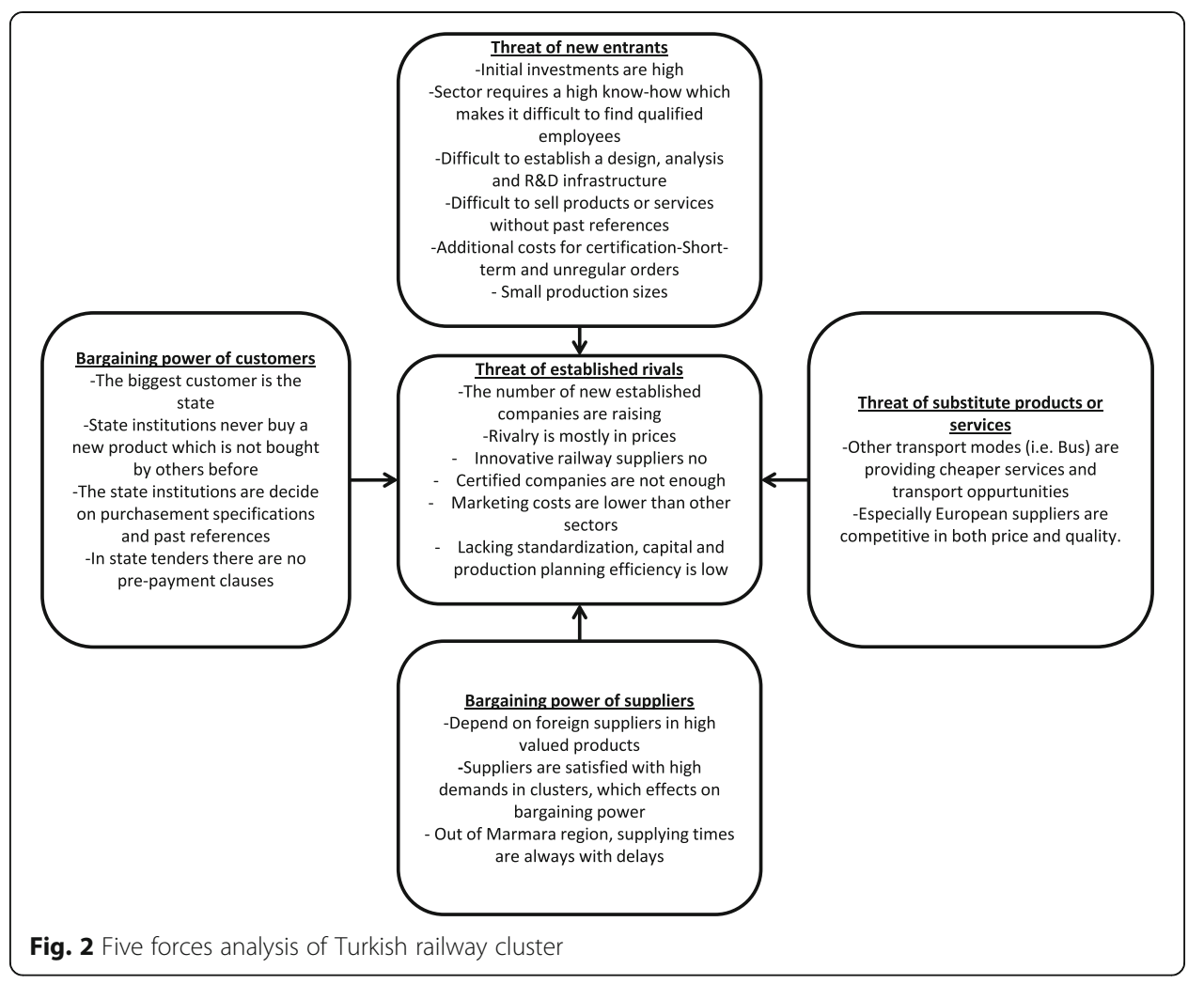

In the study, the SWOT analysis is used to show the strong and weak points of the Turkish railway cluster to compare and validate these factors with the outputs of Diamond and Five Forces models. It aims also to strengthen the opportunities and mitigate threats of the cluster (see Fig. 3).

\section{Interpretation of the results}

All applied models gave the results of a railway cluster analysis in which 93 suppliers were questioned and data collected. The interpretation is based on the characteristics of the most found answers of each supplier. However, the Diamond Model has 6 dimensions, Five Forces Model 5 and SWOT only 4, it came out that the results are almost similar.

A cluster's performance in competitiveness is decided by the cluster members' (suppliers) characteristics (Karniouchina et al., 2013). Therefore, the analysis is separated in cluster and suppliers scores to relate the suppliers' characteristics with cluster competition performance.

From this, a universal choice set consisting of the most effective criteria on cluster performances in railway industry are defined. The panel of experts decided only to consider as the most important factors the ones which were given as an answer by more than $\% 70$ of the companies. Thus, the threshold value was set to $\% 70$ (marked in bold text in the Table 1) to filter and reduce the factors to a more manageable criteria list. The score is calculated according to the number of responses by 93 companies. For example; restriction of physical size of production plant is an important competiveness factor for 74 companies in 93 , which makes $\%$ 


\begin{tabular}{|c|c|}
\hline STRENGHTS & WEAKNESSES \\
\hline $\begin{array}{l}\text { - } \\
\text { members } \\
\text { - } \\
\text { - } \quad \text { Easy actitive industry } \\
\text { markets } \\
\text { - } \quad \text { Lower labor costs compared to Europe } \\
\text { High numbers of companies intended to invest into the } \\
\text { railway sector } \\
\text { Almost all companies have a certified quality } \\
\text { management system } \\
\text { Most of the companies are located in techno parks or } \\
\text { industrial zones. }\end{array}$ & 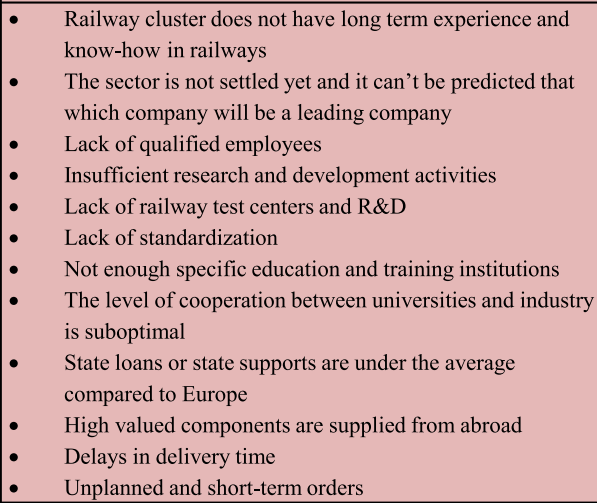 \\
\hline OPPURTUNITIES & \begin{tabular}{|c|} 
THREATS \\
\end{tabular} \\
\hline $\begin{array}{l}\text { - } \text { Government investments are planned according to its } \\
2023 \text { aims in huge amounts } \\
\text { - } \\
\text { Railway sector will be opened for competition by the } \\
\text { end of } 2016 \\
\text { - New state support law (draft). } \\
\text { Know-how transfer from foreign companies through } \\
\text { common projects } \\
\text { - } \quad \text { Nery strong automotive industry } \\
\text { - } \quad \text { New regulation for upcoming tenders which protects } \\
\text { - } \quad \text { Main European companies are shifting to East } \\
\text { - Countries } \\
\text { Regional governments are also investing in mass light } \\
\text { rail projects }\end{array}$ & $\begin{array}{l}\text { - As Turkish Railway market is a new and emerging market, } \\
\text { Far East country suppliers could change strategy (i.e. } \\
\text { raising quality standards) not to lose market share. } \\
\text { The State's continuing purchasement from abroad } \\
\text { - Risk of not spreading out the localization ratio of } \% 51 \text { in } \\
\text { product purchasements with the new draft law } \\
\text { The State's continuing low risk behavior (not to buy new } \\
\text { developed products) } \\
\text { Difficulties in land and construction investments due to } \\
\text { continuously rising prices } \\
\text { Especially, Chinese product range is raising not only in } \\
\text { global but also in Turkish market } \\
\text { Size restrictions of plants for future development }\end{array}$ \\
\hline
\end{tabular}

80 as score if 74 , is divided by 93 . Only 10 criteria scored $50 \%$ and above by different answers which are also shown in the Table 1.

Although the models are qualitative, due to different approaches of the models, as seen in Table 1, not all related answers are found in the models. That is due to the further filtering of the criteria. Hence, a threshold value for the scores over 70\% (marked in bold text in the Table 1) is defined for the Table to define the criteria as most effective. As a result, the main findings effecting clusters' performance would be: the delivery time of suppliers (91\%), lack of qualified staff (83\%), capital of companies (82\%), the physical enlargement area of the suppliers' production plant $(80 \%)$, cluster localization (close or far to the suppliers and customers) and access to different transport modes (74\%) respectively. Access to the different transport modes, logistics, among other factors, should also be considered as a very important factor from the perspective of national competition (Hämäläinen et al., 2017). It can be seen from Table 1 that the dimensions of the models do not have an effect on the determination of the most important competition performance criteria. All applied models provided similar results and are consistens as explained above.

To precise and verify the outputs of this study, an analysis on the Turkish railway industry's evolution was applied via one of the most frequently used analysis tool that is Porters' (1998) industries life cycle model. Thus, it can be assumed that different industries have similar life cycles in terms of industry sales and time. This life cycle is separated by Michel Porter into "introduction", "growth", "maturity" and "decline" phases (Karniouchina et al., 2013). 
After the analysis of the life cycle phase of Turkey's railway cluster according to our database collected from the cluster firms, it came out that the Turkish railway cluster is between introduction and growth phase (see Fig. 1). This phase has typical characteristics such as high investment demand, lack of qualified staff due to missing know-how in the sector, low efficiency (effecting delivery times), unclearness in strategies and slow development (in R\&D-innovation, marketing etc.). Therefore, chosen performance criteria can be verified via these industry life cycle analysis and its' specific characteristics.

As it can be seen from Fig. 4, performance criteria chosen according to their score points are complying with the life cycle curve section and reflecting the typical characteristics of Turkish Railway Cluster in this phase of life cycle cut. This shows another main finding that all applied models are providing meaningful, objective and expected results and they can be used as supportive decision tools for strategy management issues.

\section{Conclusions}

As Porter introduced the Diamond and Five Forces Model, he expressed that elements of his model possess effect on competitiveness, whereas SWOT Analysis also provided a similar result as it is close to the Five Forces Model. To sum up, this research is seeking for answers to determine which performance criteria are the most effective ones in addition to Porter's study and tries to deal with the problematic issues by choosing the right decision model to verify the results. The consistencies of different models are also checked in the study.

As expected, the performance criteria of a cluster companies were firstly affected by countries frame conditions such as government policies, subsidies, regulations, investments etc. and localization (distance to transport modes and logistics chain) of the cluster. The competitiveness here is only focused on international level. Results of this study shows that the most important competitiveness performance criteria of a railway cluster are, according to the importance; delivery time of suppliers, qualified staff, capital of companies and physical enlargement area of suppliers' production plant. The innovation capability factor such as; R\&D Department existence and investments in $R \& D$ were not measured as important for the cluster members. Thus, the innovation capability of the companies are considered as low as the railway industry is a slow developing sector in terms of technology.

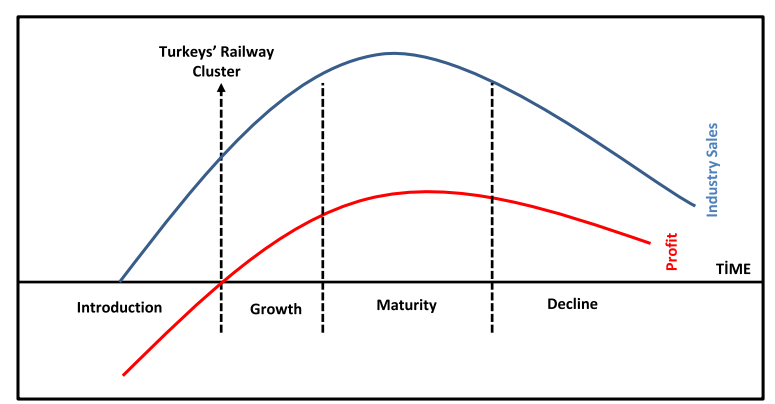

Fig. 4 Phases of industry life cycle and the analysis of Turkish railway cluster 
Although, all applied models have different dimensions and aspects, they all provide the same results regardless of their dimensions. It can be said that all of the models applied for cluster analysis are consistent and can be used as a strategic decision tools for improvements.

As for another result, it was found that our sample scale could be used as a valid and reliable measurement of the research. However, it is recommended to apply these models also in other clusters and with more different cluster research models e.g. Double Diamond Model, Nine-Factor Model to have comparable results of the analysis.

\section{Acknowledgements}

I would like to convey my gratefulness to the company Piri Group and colleagues for the excellent work and providing the availability of data for this opportunity.

\section{Funding}

Not applicable.

\section{Availability of data and materials}

The data and material included into this paper are filtered according to the agreement with the stakeholders and participants of the research. The data given here is permitted for publication. A publicly archived data set is not used, all data and material are generated during the study. For the case of privacy limitations and third-party control — authors made only the permitted parts available in the paper.

\section{Authors' contributions}

First Author; Mr. MTA was hired by the Piri Group Company for the research of the Turkish railway cluster with the permission of the Ministry of Economy to ensure the gaps of the market with the aim to highlight the threats, opportunities, strengths and weakness of the railway cluster in a scientific way. Second Author; Mr. KY supported the research in the second phase; to turn the results into an more comprehensive analysis by adding Porter's SWOT, Diamond Analysis and Five Forces Analysis methods to make a comparison between different scientific economic models to figure out the consistency between these models and also to highlight the most important performance criteria of the railway cluster. Both authors read and approved the final manuscript.

Ethics approval and consent to participate

It is approved by the Authors.

Consent for publication

It is approved by the Authors.

Competing interests

The authors declare that they have no competing interests.

\section{Publisher's Note}

Springer Nature remains neutral with regard to jurisdictional claims in published maps and institutional affiliations.

\section{Author details}

${ }^{1}$ Gazi University Technology Faculty Civil Engineering Department Teknikokullar - Beşevler, Çankaya, 06570 Ankara,

Turkey. ${ }^{2}$ Gazi University Rektörlüğü, Teknoloji Fakültesi İnşaat Mühendisliği Bölümü, Teknikokullar, 06500 Ankara, Turkey.

Received: 5 December 2017 Accepted: 19 January 2018

Published online: 13 February 2018

\section{References}

Adler, M., \& Ziglio, E. (1996). Gazing into the oracle. Bristol, PA: Jessica Kingsley Publishers.

Allen, R. C. (1983). Collective invention. Journal of Economic Behavior and Organization, 4(1), 1-24. https://doi.org/10. 1016/0167-2681(83)90023-9.

Arsezen-Otamisa, P., \& Yuzbasioglu, N. (2013). Analysis of Antalya tourism cluster perceived performance with structural equation model. Procedia - Social and Behavioral Sciences, 99, 682-690. https://doi.org/10.1016/j.sbspro.2013.10.539

Arthur, W. B. (1989). Competing technologies, increasing returns, and lock-in by historical events. The Economic Journal, 99(394), 116. https://doi.org/10.2307/2234208

Asheim, B. T., \& Coenen, L. (2005). Knowledge bases and regional innovation systems: Comparing Nordic clusters. Research Policy, 34(8), 1173-1190. https://doi.org/10.1016/j.respol.2005.03.013

Bell, G. G. (2005). Clusters, networks, and firm innovativeness. Strategic Management Journal, 26(3), 287-295. https://doi.org/10.1002/smj.448

Bessant, J., von Stamm, B., Moeslein, K. M., \& Neyer, A. K. (2010). Backing outsiders: Selection strategies for discontinuous innovation. $R$ and D Management, 40(4), 345-356. https://doi.org/10.1111/j.1467-9310.2010.00606.x 
Caltagirone, S., Pendergast, A., \& Betz, C. (2013). The diamond model of intrusion analysis. Threat Connect, 298(704), 1-61. http://www.activeresponse.org/wp-content/uploads/2013/07/diamond.pdf. https://www.threatconnect.com/ wp-content/uploads/ThreatConnect-The-Diamond-Model-of-Intrusion-Analysis.pdf

Celiktas, M. S., \& Kocar, G. (2010). From potential forecast to foresight of Turkey's renewable energy with Delphi approach. Energy, 35(5), 1973-1980. https://doi.org/10.1016/j.energy.2010.01.012

Chen, S., \& Ning, J. (2002). Constraints on E-commerce in less developed countries: The case of China. Electronic Commerce Research, 2, 31-42.

Cho, D.-S., \& Moon, H.-C. (2013). From Adam smith to Michael porter:Evolution of competitiveness theory. World Scientific Books http://ideas.repec.org/b/wsi/wsbook/8451.html

Cooke, P. (2002). Knowledge economies. Routledge studies in international business and the world economy. https://doi.org/10.4324/9780203445402

FME. (2013). SWOT analysis: Strategy skills. Free-Managment-Ebooks. http://www.free-management-ebooks.com/dldebk$\mathrm{pdf} / \mathrm{fme}$-pestle-analysis.pdf

Freeman, C. (1991). Networks of innovators: A synthesis of research issues. Research Policy, 20(5), 499-514. https://doi. org/10.1016/0048-7333(91)90072-X.

Greenspan, R. (2015). Walmart: Five forces analysis (Porter's model). Panamore Institute.

Grieger, J. A., Scott, J., \& Cobiac, L. (2012). Cluster analysis and food group consumption in a national sample of Australian girls. In Journal of Human Nutrition and Dietetics, 25, 75-86. https://doi.org/10.1111/j.1365-277X. 2011.01195.x

Hämäläinen, E., Twrdy, E., \& Inkinen, T. (2017). Cost aggregation in export logistics chain. Journal of Open Innovation: Technology, Market, and Complexity, 3(1), 26 https://doi.org/10.1186/s40852-017-0077-9

Helmer, O. (1977). Problems in futures research. Delphi and causal cross-impact analysis. Futures, 9(1), 17-31. https://doi.org/10.1016/0016-3287(77)90049-0

International Energy Agency (IEA), Market Report Series: Energy Efficiency 2017. http://www.iea.org/publications/ freepublications/publication/market-report-series-energy-efficiency-2017-html Accessed 25 Jan 2018.

Jin, B., \& Moon, H.-C. (2006). The diamond approach to the competitiveness of Korea's apparel industry: Michael porter and beyond. Journal of Fashion Marketing and Management, 10(2), 195-208. https://doi.org/10.1108/ 13612020610667504

Karniouchina, E. V., Carson, S. J., Short, J. C., \& Ketchen, D. J. (2013). Extending the firm vs. industry debate: Does industry life cycle stage matter? Strategic Management Journal. https://doi.org/10.1002/smj.2042

Lundvall, B.-Å. (1988), 'Innovation as an interactive process: From user-producer interaction to the National Innovation Systems', in Dosi, G., Freeman, C., Nelson, R.R., Silverberg, G. and Soete, L.,(eds.), Technology and economic theory, London, Pinter Publishers.

Magnier-Watanabe, R., \& Benton, C. (2017). Management innovation and firm performance: The mediating effects of tacit and explicit knowledge. Knowledge Management Research \& Practice, 15(3), 325-335 https://doi.org/ $10.1057 /$ s41275-017-0058-6

Mansury, M. A., \& Love, J. H. (2008). Innovation, productivity and growth in US business services: A firm-level analysis. Technovation, 28. https://doi.org/10.1016/j.technovation.2007.06.002

Novelli, M., Schmitz, B., \& Spencer, T. (2006). Networks, clusters and innovation in tourism: A UK experience. Tourism Management, 27(6), 1141-1152. https://doi.org/10.1016/j.tourman.2005.11.011

Park, J.-H., Lee, B., Moon, Y.-H., \& Kwon, L.-N. (2016). Study for selection of industrial areas suitable to small and medium-sized enterprises (SMEs) in Korea. Journal of Open Innovation: Technology, Market, and Complexity, 2(1), 19 https://doi.org/10.1186/s40852-016-0045-9

Popper, R. (2008). How are foresight methods selected? Foresight, 10. https://doi.org/10.1108/14636680810918586

Porter, A. L. (2010a). Technology foresight: Types and methods. International Journal of Foresight and Innovation Policy, 6(1), 36-45. https://doi.org/10.1504/IJFIP.2010.032664

Porter, E., \& M. (2011). Porter five forces analysis. Wikipedia.

Porter, M. (2010b). Porter's five forces. What makes a Good Leader, 2011(78-93), 137 http://www.quickmba.com/ strategy/porter.shtml

Porter, M. (1990). Competitive Advantage of Nations. Competitive Intelligence Review, 1(1), 14-14. https://doi.org/10. 1002/cir.3880010112.

Porter, M. E. (1998). Clusters and the new economics of competition. Harvard Business Review, 76-77(6), 77-90. https://doi.org/10.1042/BJ20111451

Porter, M. E. (1999). Michael porter on competition. Antitrust Bulletin, 44(4), 841 http://search.ebscohost.com/login. aspx?direct=true\&db=bth\&AN=2997379\&site=eds-live

Porter, M. E. (2002a). Enhancing the microeconomic foundations of prosperity: The current competitiveness index, The global competitiveness report (pp. 52-76). Geneva: World Economic forum.

Porter, M. E. (2002b). Enhancing the microeconomic foundations of prosperity: The current competitiveness index, The global competitiveness report (pp. 52-76). Geneva: World Economic forum.

Porter, M. E. (2008). The five competitive forces that shape strategy. Harvard Business Review, 86(1). https://doi.org/ Article.

Reynders, E. (2012). System identification methods for (operational) modal analysis: Review and comparison. Archives of Computational Methods in Engineering, 19(1), 51-124. https://doi.org/10.1007/s11831-012-9069-x

Riasi, A. (2015). Competitive advantages of shadow banking industry: An analysis using porter diamond model. Business Management and Strategy, 6(2), 15. https://doi.org/10.5296/bms.v6i2.8334

Rice, J. F. (2010). Adaptation of Porter's five forces model to risk management. Defense AR Journal, 17, 375-388 https://www.dau.mil/cop/space/_layouts/15/WopiFrame.aspx?sourcedoc=/cop/space/ DAU\%20Sponsored\%20Documents/Aug\%2011\%20High\%20Frontier.pdf\&action=default\&DefaulttemOpen=1

Rothgang, M., Cantner, U., Dehio, J., Engel, D., Fertig, M., Graf, H., et al. (2017a). Cluster policy: Insights from the German leading edge cluster competition. Journal of Open Innovation: Technology, Market, and Complexity, 3(1), 18 https://doi.org/10.1186/s40852-017-0064-1 
Rothgang, M., Dehio, J., \& Lageman, B. (2017b). Analysing the effects of cluster policy: What can we learn from the German leading-edge cluster competition? Journal of Technology Transfer, pp., 1-25 https://doi.org/10.1007/s10961-017-9616-6

Rugman, A. M., \& D'Cruz, J. R. (1993). The "double diamond" model of international competitiveness: The Canadian experience. Management International Review, 33, 17-39. https://doi.org/10.2307/40228188

Solvell, O. (2008). Clusters, balancing evolutionary and constructive forces. Stockholm: Ivory Tower Publishers.

Sztuka, A. (2011). Branchenstrukturanalyse (five forces) nach porter. Manager Wiki. http://www.manager-wiki.com/index php/externe-analyse/22-branchenstrukturanalyse-qfive-forcesq-nach-porter

Terzić, Z., Vukasinović, Z., Bjegović-Mikanović, V., Jovanović, V., \& Janicić, R. (2011). SWOT Analysis. Dictionary of Marketing Communications. https://doi.org/10.4135/9781452229669.n3585

Tödtling, F., \& Trippl, M. (2005). One size fits all?: Towards a differentiated regional innovation policy approach. Research Policy, 34(8), 1203-1219. https://doi.org/10.1016/j.respol.2005.01.018

Tseng, F. M., \& Cheng, A. C. (2009). Combining scenario analysis with delphi and the technological substitution model to analyze the development of the oled tv market. In In PICMET: Portland International Center for Management of engineering and technology, proceedings (pp. 2415-2425). https://doi.org/10.1109/PICMET.2009.5261832

Turoff, M., Hiltz, S. R., White, C., Plotnick, L., Hendela, A., \& Yao, X. (2009). The past as the future for emergency planning and response. International Journal of Information Systems for Crisis Response and Management (IJISCRAM), 1(1), 12-28. https://doi.org/10.4018/jiscrm.2009010102

Viederyte, R., \& Didziokas, R. (2014). Cluster models, factors and characteristics for the competitive advantage. Economics and Management, 19(2), 162-171. https://doi.org/10.5755/j01.em.19.2.4197

Submit your manuscript to a SpringerOpen ${ }^{\circ}$ journal and benefit from:

- Convenient online submission

- Rigorous peer review

- Open access: articles freely available online

- High visibility within the field

- Retaining the copyright to your article

Submit your next manuscript at $>$ springeropen.com 